\title{
Phenotypic recurrent selection in the common bean (Phaseolus vulgaris $L$ ) with carioca-type grains for resistance to the fungi Phaeoisariopsis griseola
}

\author{
Geovani Bernardo Amaro ${ }^{1}$, Ângela de Fátima Barbosa Abreu², Magno Antonio Patto Ramalho ${ }^{1}$ \\ and Flávia Barbosa Silva ${ }^{1}$ \\ ${ }^{I}$ Departamento de Biologia, Universidade Federal de Lavras, Lavras, MG, Brazil. \\ ${ }^{2}$ Departamento de Biologia, Embrapa Arroz e Feijão/UFLA, Lavras, MG, Brazil.
}

\begin{abstract}
The efficiency of recurrent selection was assessed in obtaining common bean (Phaseolus vulgaris $L$ ) plant lines resistant to the phytopathogenic fungi Phaeoisariopsis griseola. The base bean population was obtained from the partial diallel between seven lines with carioca-type grains and 10 sources of resistance to $P$. griseola. The plants most resistant to the pathogen were selected in the $\mathrm{F}_{2}\left(\mathrm{~S}_{0}\right)$ generation of the populations $(C-0)$. The best $\mathrm{S}_{0: 1}$ plants that presented carioca-type grains were intercrossed to obtain cycle I (C-I). The same procedure was adopted to obtain cycles C-II to C-V. In each recurrent selection cycle, $S_{0: 1}$ progenies selected were also assessed in experiments carried out in Lavras, Brazil, always using as check the Carioca MG (susceptible to $P$. griseola) and Pérola (tolerant) cultivars. The response to selection for resistance to the pathogen was estimated from the general mean of the $S_{0: 1}$ progenies from each selective cycle compared to the susceptible check Carioca MG. The estimated gain was $6.4 \%$ per cycle and the indirect response in grain yield by selection for resistance to the pathogen was $8.9 \%$ per cycle. The variability detected among the progenies in the last selective cycles enabled the prediction of additional responses to recurrent selection.
\end{abstract}

Key words: angular-leaf-spot, grain yield, heritability, Phaseolus vulgaris, response to selection.

Received: May 23, 2006; Accepted: November 16, 2006.

\section{Introduction}

During the last 20 years problems with phytopathogens have increased with the intensification of common bean (Phaseolus vulgaris L) cultivation in Brazil. These phytopathogens include the fungi Phaeoisariopsis griseola, which cause the angular-leaf-spot that has been highlighted due to the considerable damage caused to the crop (Miklas et al., 2006). The importance of P. griseola is increasing in the Brazilian state of Minas Gerais, especially in the February-March dry season, because of the favorable climatic conditions for the development of the pathogen. The use of resistant $P$. vulgaris cultivars is the main control measure for $P$. griseola (Miklas et al., 2006) but it is difficult to obtain lines with long-lasting resistance (PastorCorrales et al., 1998). Although there is still doubt regarding genetic control, several genes must be involved (Mahuku et al., 2004), especially because of the proven existence of several pathogen races (Sartorato and Alzate-Marin, 2004).

Send correspondence to Ângela de Fátima Barbosa Abreu. Universidade Federal de Lavras, Departamento de Biologia, Caixa Postal 3037, 37200-000 Lavras, MG, Brazil. E-mail: afbabreu@ ufla.br.
Recurrent selection is one of the alternatives for accumulating several resistance alleles (Ramalho et al., 2001). As the resistance to angular leaf spot normally has relatively high heritability plants can be phenotypically selected for recombination in the $\mathrm{F}_{2}$ generation. Since no reports were found in the literature regarding the use of recurrent selection of $P$. vulgaris for resistance to pathogens this study was carried out to assess the efficiency of phenotypic recurrent selection in obtaining progeny resistant to $P$. griseola and to verify the effects of such selection on grain yield.

\section{Materials and Methods}

Biparental crossings were made between the seven (Phaseolus vulgaris L) cultivars with carioca type grains (Carioca MG, CI-140, CI-128, ANPAT 8.12, IAPAR 81, ESAL 693 and Pérola) and 10 sources of resistance to $P$. griseola (AN 512561, AND 277, Ouro Negro, Compuesto Negro Chimaltenango, CAL 143, MAR 2, MAR 1, G 5686, MA 4.137 and Jalo) with several grain types. The seeds came from Universidade Federal de Lavras Germplasm Bank. The crosses were performed in a greenhouse at the Departamento de Biologia/Universidade Federal de 
Lavras, Minas Gerais (MG), Brazil in the 1998 winter season (sown in July). Twenty-nine hybrid combinations were obtained $\left(\mathrm{F}_{1}\right)$ because of the incompatibility of some crosses (Singh and Gutiérrez, 1984). These hybrids were sown in November of the same year to obtain the $F_{2}\left(S_{0}\right)$ seeds that formed the base population, or cycle $0(\mathrm{C}-0)$, population. This population was sown in the1999 dry season that presents favorable environmental conditions for angular-leaf-spot and at the end of the cycle the most resistant plants from each cross were phenotypically selected.

To obtain the cycle I (C-I, sown in 2001) population the 29 best $\mathrm{S}_{0: 1}$ plants from C-0 population were intercrossed, one per population, selected phenotypically for resistance to $P$. griseola and including those plants presenting carioca type grains as close as possible to the market standard of beige grains with pale brown stripes. The plants from each population were intercrossed with another two plants according to the scheme presented by Ramalho et al. (2001). Recombination was performed In the 2000 autumn-winter season and the $F_{1}$ generation obtained and sown in the 2000 wet season to obtain the $S_{0}$ seeds of the following cycle. The same procedure was adopted to obtain one selective cycle per year. i.e. cycle II (C-II, sown in 2002), cycle III (C-III, sown in 2003), cycle IV (C-IV, sown in 2004) and cycle V (C-V, shown in 2005).

In the region, conditions favorable to the development of $P$. griseola occur in the February-March dry season, so the $\mathrm{S}_{0}$ generation was always evaluated in this season. In addition to selecting plants for recombination, in the $\mathrm{S}_{0}$ generation of each recurrent selection cycle, a further 20 to 30 plants were selected from each population to form the $\mathrm{S}_{0: 1}$ progenies that were assessed in experiments carried out in Lavras, MG, always using the $P$. griseola susceptible Carioca MG and $P$. griseola tolerant Pérola cultivars as checks. The seeds from each plant formed one progeny.

Table 1 shows the details of the number of $\mathrm{S}_{0: 1}$ progenies assessed in each recurrent selection cycle, the experimental design, plot size (one two-row spaced at $0.5 \mathrm{~m}$ ) and seasons. All the experiments assessed the grain yield in $\mathrm{g} \mathrm{m}^{-2}$ and the severity of angular-leaf-spot, the latter being scored using the following nine-point scale: $1=$ asymptomatic plants; $2=$ up to $3 \%$ of the leaf area covered with non-sporulated lesions; $3=$ up to $5 \%$ of the leaf area cov-

Table 1 - Number of $S_{0: 1}$ progenies from each cycle of the recurrent selection program, experimental design, plot size and sown date. The plot size in each case was one two-metre row. All plots were sown in February.

\begin{tabular}{lccc}
\hline Cycle & $\begin{array}{c}\text { Number of } \\
\text { progeny }\end{array}$ & $\begin{array}{c}\text { Simple lattice experimental } \\
\text { design }\end{array}$ & Year \\
\hline C-I & 223 & $15 \times 15$ & 2001 \\
C-II & 322 & $18 \times 18$ & 2002 \\
C-III & 194 & $14 \times 14$ & 2003 \\
C-IV & 287 & $17 \times 17$ & 2004 \\
C-V & 254 & $16 \times 16$ & 2005 \\
\hline
\end{tabular}

ered with non-sporulated lesions; $4=$ about $10 \%$ of the leaf area covered with sporulated lesions; $5=$ several $2 \mathrm{~mm}$ or $3 \mathrm{~mm}$ sporulated lesions covering approximately 10 to $15 \%$ of the leaf area; $6=$ numerous sporulated lesions larger than $3 \mathrm{~mm}$ and covering $15-20 \%$ of the leaf area; $7=$ as for 6 but covering 20 to $25 \%$ of the leaf area; $8=$ as for 6 but covering 25 to $35 \%$ of the leaf area and generally associated with chlorotic tissues that could coalesce and form extensive infected areas; 9 - severe disease symptoms resulting in premature leaf fall and death.

The data obtained for angular-leaf-spot severity and grain yield of the progeny from each cycle were submitted to variance analysis considering all the effects as random except the mean. The genetic variance $\left(\hat{\sigma}_{G}^{2}\right)$, phenotypic variance $\left(\hat{\sigma}_{F}^{2}\right)$ and broad-sense heritability $\left(h^{2}\right)$ were estimated according to Ramalho et al. (1993), the lower and upper limits for the confidence intervals for the $h^{2}$ estimates being obtained according Knapp et al. (1985).

The response to recurrent selection cycles was estimated for the reaction to angular-leaf-spot and grain yield using the $\mathrm{S}_{0: 1}$ progenies performance of the five selection cycles. Because the $S_{0: 1}$ progenies from each cycle were assessed in different years for angular-leaf-spot severity, to attenuated the environment effect the genetic deviation $(d g)$ was obtained from the difference between the mean of the susceptible Carioca MG check cultivar and the mean of the $\mathrm{S}_{0: 1}$ progenies for each cycle as $d g=$ mean of Carioca MG assessed in the same season as the progenies in cycle $i$ minus the mean of the $\mathrm{S}_{0: 1}$ progenies in cycle $i$. The linear regression equation was obtained for the number of cycles, independent variable $(x)$ and the genetic deviation, dependent variable $(y)$. The percentage response to selection $R s(\%)$ per recurrent selection cycle in relation to the mean of the $\mathrm{S}_{0: 1}$ progenies of C-I was calculated as: $R s(\%)=\left(b_{1} / \bar{X}_{C I}\right) \times 100$, $\mathrm{b}_{1}$ is the linear regression coefficient and $\bar{X}_{C I}$ is the mean of the $\mathrm{S}_{0: 1}$ progenies for cycle 1 (C-I). The same procedure was used to estimate the response to selection for grain yield, but the genetic deviation of the $\mathrm{S}_{0: 1}$ progenies was estimated compared to the mean of the two checks.

\section{Results and Discussion}

There was significant difference between the $\mathrm{S}_{0: 1}$ progenies in all of the cycles for the angular-leaf-spot severity scores, indicating the existence of variability among the progenies for resistance to $P$. griseola. The estimates of the genetic and phenotypic parameters confirm this observation (Table 2). In most cases the $h^{2}$ estimates were high and exceeded $60 \%$, with most of the estimates of the lower limit of the $h^{2}$ values being positive and hence indicating that the estimates should be different from zero at the $95 \%$ probability level. Variability between the $\mathrm{S}_{0: 1}$ generation progenies can also be observed in Table 3. The range of angular-leaf-spot severity scores was high in all of the cycles.

In the comparative assessment of pathogen severity during different years and/or locations the environmental 
Table 2 - Genetic variance $\left(\hat{\sigma}_{G}^{2}\right)$ and phenotypic variance $\left(\hat{\sigma}_{F}^{2}\right)$ estimates between means of progenies and broad-sense heritability $\left(h^{2}\right)$ with its respective lower (LL) and upper (UL) limit of the $\mathrm{S}_{0: 1}$ generation in the first to fifth recurrent selection cycle for the angular-leaf-spot disease severity score.

\begin{tabular}{lllllll}
\hline \multirow{2}{*}{ Cycle } & \multicolumn{2}{c}{ Variance } & & \multicolumn{3}{c}{ Broad sense heritability } \\
\cline { 2 - 3 } \cline { 6 - 7 } & Genetic & Phenotypic & & $(\%)$ & LL & UL \\
\hline C-I & 0.904 & 1.644 & & 55.00 & 40.97 & 65.78 \\
C-II & 1.048 & 1.619 & & 64.74 & 55.87 & 71.87 \\
C-III & 0.354 & 0.558 & & 63.52 & 48.81 & 72.83 \\
C-IV & 0.469 & 0.665 & & 70.58 & 62.66 & 76.85 \\
C-V & 0.038 & 0.173 & & 21.81 & -0.64 & 39.52 \\
\hline
\end{tabular}

effect is often difficult to assess and to attenuate this problem a susceptible check cultivar, such as the $P$. griseola susceptible Carioca MG cultivar, can be used. In our $\mathrm{S}_{0: 1}$ generation assessments the mean score attributed to the Carioca MG check cultivar varied slightly but the values were high (Table 3 ), indicating, as previously mentioned, that the conditions for pathogen development were favorable in the dry season.

We found that the general mean of the progenies over the selective cycles tended to decrease, indicating that the level of resistance increased during the cycles. The same occurred when the $P$. griseola tolerant Pérola cultivar was used as the check cultivar, this cultivar showing a good level of resistance to $P$. griseola in the locations assessed. However, over the selected cycles the mean disease severity score of the progeny tended to be lower than of the Pérola cultivar (Table 3 ).

We also detected significant variation $(\mathrm{p}<0.01)$ in the analysis of variance for grain yield among the $S_{0: 1}$ progenies in all the five recurrent selection cycles. The estimates of the genetic and phenotypic parameters supported the results of the variance analyses (Table 4 ). The $h^{2}$ estimates for the $\mathrm{S}_{0: 1}$ generation in the different cycles (Table 4) all exceeded $25 \%$, although a small reduction in the $\mathrm{h}^{2}$ estimates occurred during the selective cycles.

Recurrent selection is a process which should be periodically assessed because the response to selection esti-
Table 4 - Genetic variance $\left(\hat{\sigma}_{G}^{2}\right)$ and phenotypic variance $\left(\hat{\sigma}_{F}^{2}\right)$ estimates between means of progenies and broad-sense heritability $\left(h^{2}\right)$ with its respective lower (LL) and upper (UL) limit of the $\mathrm{S}_{0: 1}$ generation in the first to fifth recurrent selection cycle for grain yield in $\mathrm{g} \mathrm{m}^{-2}$.

\begin{tabular}{lcclcccc}
\hline \multicolumn{3}{c}{ Variance } & & \multicolumn{3}{c}{ Broad sense heritability } \\
\cline { 1 - 2 } \cline { 6 - 7 } Cycle & Genetic & Phenotypic & & $(\%)$ & LL & UL \\
\hline C-I & 1125.12 & 2655.28 & & 42.37 & 24.39 & 56.18 \\
C-II & 2329.16 & 4698.88 & & 49.57 & 36.87 & 59.76 \\
C-III & 2260.13 & 3894.66 & & 58.03 & 43.82 & 68.73 \\
C-IV & 927.03 & 2404.04 & & 38.56 & 22.03 & 51.66 \\
C-V & 1002.71 & 3906.38 & & 25.67 & 4.21 & 42.43 \\
\hline
\end{tabular}

mates in different periods allows breeders to verify the success attained and where alterations are required in the procedures used. In allogamous plants, the response to selection estimates are easily obtained by assessing the populations of the different cycles, because in such plants the population returns to the normal condition of equilibrium after recombination. Thus one sample from the populations of each cycle should be stored for later assessment. However, in the case of the common bean P. vulgaris this procedure cannot be used because after intercrossing selffertilization occurs in the succeeding generations and the genotypic frequencies and, consequently, the genetic properties are altered. Because of this, some alternatives strategies have been used to obtain responses to selection, one such strategy is the to use the mean performance of the $S_{0: 1}$ or $\mathrm{S}_{0: 2}$ progenies in each cycle based on the performance of the common check cultivars as an indicator of environmental fluctuation (Olmedo et al., 1995). A somewhat different strategy is to use the $\mathrm{S}_{2}$ and $\mathrm{S}_{3}$ progenies chosen as a function of the trait under selection (Ranalli, 1996; Singh et al., 1999) and it is also possible to use the best lines identified in the different cycles (Ramalho et al., 2005).

We obtained a response to selection estimates using the means of the $\mathrm{S}_{0: 1}$ generations of the five selective cycles compared to the Carioca MG check cultivar to attenuate the environmental effect on the severity of angular-leaf-spot (Table 5). The deviation from the progeny mean compared to the Carioca MG check cultivar tended to increase during

Table 3 - Angular-leaf-spot severity score $(1=$ minimum, 9 = maximum $)$ and grain yield in $\mathrm{g} \mathrm{m}^{-2}$ of the progenies and the Carioca MG and Pérola checks assessed from the first $(\mathrm{C}-\mathrm{I})$ to fifth $(\mathrm{C}-\mathrm{V})$ recurrent selection cycle.

\begin{tabular}{lccccccc}
\hline & \multicolumn{2}{c}{ Angular-leaf-spot severity score } & & \multicolumn{3}{c}{ Grain yield } \\
\cline { 2 - 3 } \cline { 6 - 8 } Cycle & Progenies & Carioca MG & Perola & & Progenies & Carioca MG & Perola \\
\hline C-I & $3.9(1.7-7.9)$ & 5.7 & 4.2 & & $177.6(65.6-393.4)^{1}$ & 187.4 & 207.9 \\
C-II & $4.5(2.1-7.8)$ & 7.6 & 5.2 & & $264.0(112.0-491.0)$ & 219.1 & 192.3 \\
C-III & $3.3(1.8-5.9)$ & 7.2 & 3.1 & & $243.9(95.0-410.9)$ & 183.0 & 177.7 \\
C-IV & $3.8(1.5-7.5)$ & 6.5 & 4.9 & & $260.5(90.4-388.5)$ & 211.1 & 228.3 \\
C-V & $2.8(1.8-4.3)$ & 6.0 & 3.6 & & $257.5(94.3-436.5)$ & 188.4 & 184.5 \\
\hline
\end{tabular}

${ }^{1}$ The parenthesis show the minimum and maximum value obtained for angular-leaf-spot severity and grain yield. 
the cycles, as discussed above. The $\mathrm{b}_{1}$ estimate was positive and different from zero, indicating that the difference among the mean scores of the progeny and Carioca MG were accentuated during the cycles, that is, the resistance level increased with selection. Taking as reference the mean of the $S_{0: 1}$ progenies of the first cycle, the gain with selection was $6.4 \%$ per selective cycle.

There are few reports in the literature about the use of recurrent selection for pathogen resistance for the common bean crop (Lyons et al., 1987; Garcia et al., 2003). However, the gain obtained in this study was expressive. Considering that genetic control studies on resistance to $P$. griseola have indicated that the resistance is monogenic and/or oligogenic (Mahuku et al., 2004), the use of recurrent selection could be questioned. Nevertheless, there are several races of this pathogen (Sartorato and Alzate-Marin, 2004) and many genes are certainly involved in the genetic control of resistance to all of these races. Furthermore, graduation was observed in the symptoms among lines considered resistant. Part of this graduation can be attributed to the environmental effect, but the existence of polygenic control of the trait should not be discounted. The response to selection estimates reinforced this observation.

The response to selection was estimated for grain yield to obtain the indirect response in the grain yield by the selection made on the pathogen severity scores. The deviation values $(d g)$ of the mean grain yield of the progenies compared to the checks increased between the cycles (Table 6$)$. The linear regression coefficient estimate $\left(b_{1}\right)$ was $15.85 \mathrm{~g} \mathrm{~m}^{-2}$, corresponding to a mean percentage gain of $8.9 \%$ per cycle compared to the mean yield of the first cycle (Table 6). This value was similar to, or greater than, that reported for selection directly on the grain yield trait (Ranalli, 1996; Singh et al., 1999; Ramalho et al., 2005). This expressive correlated response is further evidence that $P$. griseola is important in the performance of $P$. vulgaris,

Table 5 - The $S_{0: 1}$ generation progeny means from the first to the fifth recurrent selection cycle (C-I to $\mathrm{C}-\mathrm{V})$, the Carioca $\mathrm{MG}$ cultivar means, the genetic deviation $(d g)$ for the Carioca MG cultivar (i.e. the Carioca MG cultivar mean minus the progeny mean), the intercept $\left(b_{0}\right)$, linear regression $\left(b_{1}\right)$ and determination $\left(R^{2}\right)$ coefficients and the response to selection $(R s)$ for the angular-leaf-spot severity score (1-9).

\begin{tabular}{lccc}
\hline Cycle & $\begin{array}{c}\mathrm{S}_{0: 1} \text { generation } \\
\text { progeny means }\end{array}$ & $\begin{array}{c}\text { Carioca MG } \\
\text { cultivar means }\end{array}$ & $\begin{array}{c}\text { Genetic } \\
\text { deviation }(d g)\end{array}$ \\
\hline C-I & 3.95 & 5.67 & 1.72 \\
C-II & 4.46 & 7.62 & 3.16 \\
C-III & 3.32 & 7.20 & 3.88 \\
C-IV & 3.80 & 6.51 & 2.71 \\
C-V & 2.83 & 6.04 & 3.21 \\
\hline$b_{0}$ & & & 2.18 \\
$b_{1}$ & & & 0.25 \\
$R^{2}(\%)$ & & & 25.14 \\
$R \mathrm{~s}(\%)$ & & & 6.32 \\
\hline
\end{tabular}

Table 6 - The $S_{0: 1}$ generation progeny means from the first to the fifth recurrent selection cycle (C-I to $\mathrm{C}-\mathrm{V})$, the combined Carioca $\mathrm{MG}$ and Pérola check cultivar mean, the genetic deviation $(d g)$ for the combined Carioca MG and Pérola check cultivar mean (i.e. the progeny mean minus the combined Carioca MG and Pérola check cultivar mean), the intercept $\left(b_{0}\right)$, the linear regression $\left(b_{1}\right)$ and determination $\left(R^{2}\right)$ coefficients and the response to selection $\left(\mathrm{Rs}_{0} \%\right)$ for grain yield $\left(\mathrm{g} \mathrm{m}^{-2}\right)$.

\begin{tabular}{lccc}
\hline Cycle & $\begin{array}{c}\mathrm{S}_{0: 1} \text { generation } \\
\text { progeny means }\end{array}$ & $\begin{array}{c}\text { Combined Carioca MG and } \\
\text { Pérola check cultivar mean }\end{array}$ & $\begin{array}{c}d g \\
\left(\mathrm{~g} \mathrm{~m}^{-2}\right)^{1}\end{array}$ \\
\hline C-I & 177.60 & 196.64 & -19.04 \\
C-II & 264.00 & 205.70 & +58.30 \\
C-III & 243.90 & 180.4 & +63.5 \\
C-IV & 260.50 & 219.7 & +40.8 \\
C-V & 257.50 & 186.4 & +71.1 \\
\hline$b_{0}$ & & & -5.27 \\
$b_{1}$ & & & 15.86 \\
$R^{2}(\%)$ & & & 48.85 \\
$R s(\%)$ & & & 8.93 \\
\hline
\end{tabular}

${ }^{1}$ Means of the progenies - Mean checks.

causing great damage to grain yield and further reinforces the fact that common bean plant breeding programs should concentrate on obtaining lines resistant to this pathogen for gain in grain yield.

The original population involved grains with little commercial acceptance and was generated by a partial diallel involving resistance sources with diverse, commercially unacceptable grain types and carioca grain type lines. Although several genes are involved in the genetic control of grain appearance (Basset, 2004) there was marked progress with selection for this trait. Although the response to selection for the grain type trait was not quantified, the progenies in the last cycle, for example, had a much superior appearance to those parental lines with carioca type grains. There are other reports in the literature of success with selection for grain type as occurred in this study (Cunha et al., 2005; Ramalho et al., 2005).

The use of recurrent selection for resistance to $P$. griseola should be continued, because variability for selection was detected even after the fifth cycle. Furthermore, the process is dynamic. If new sources of resistance were identified, they could be recombined together with the selected progeny and the variability could certainly be maintained during long-term selection.

We should emphasize that it was possible to carry out a selected cycle each year, contradicting the argument that recurrent selection is a slow process. This is especially true because in each cycle the endogamy advance process is carried out until lines are obtained, as in any other breeding method applied to autogamous plants.

\section{Acknowledgements}

The authors thank CNPq for granting scholarships. 


\section{References}

Basset MJ (2004) List of genes - Phaseolus vulgaris L. Ann Rep Bean Improv Coop 47:1-24.

Cunha WG da, Ramalho, MAP and Abreu A de FB (2005) Selection aiming at upright growth habit common bean with carioca type grains. Crop Breed Appl Biotech 5:379-386.

Garcia RE, Robinson RA, Aguilar JAP, Sandoval SS and Guzman RP (2003) Recurrent selection for quantitative resistance to soil borne diseases in beans in the Mixteca region, México. Euphytica 130:241-247.

Knapp SJ, Stoup WW and Ross WM (1985) Exact confidence intervals for heritability on a progeny mean basis. Crop Sci 25:192-194.

Lyons ME, Dickson MH and Hunter JE (1987) Recurrent selection for resistance to white mold in Phaseolus species. J Am Soc Hort Sci 112:149-152.

Mahuku G, Montoya C and Henriquez MA (2004) Inheritance and characterization of angular leaf spot resistance gene present in common bean accession G 10474 and identification of na AFLP marker to the resistance gene. Crop Sci 44:1817-1824.

Miklas PN, Kelly JD, Beebe SE and Blair MW (2006) Common bean breeding for resistance against biotic and abiotic stresses: From classical to MAS breeding. Euphytica 147:105-131.

Olmedo AOB, Elias EM and Cantrell RG (1995) Recurrent selection for grain yield in durum wheat. Crop Sci 35:714-719.
Pastor-Corrales MA, Jara C and Singh SP (1998) Pathogenic variation in, sources of, and breeding for resistance to Phaeoisariopsis griseola causing angular leaf spot in common bean. Euphytica 103:161-171.

Ramalho MAP, Abreu A de FB and Santos JB dos (2005) Genetic progress after four cycles of recurrent selection for yield and grain traits in common bean. Euphytica 144:23-29.

Ramalho MAP, Abreu A de FB and Santos JB dos (2001) Melhoramento de espécies autógamas. In: Nass LL, Valois ACC, Melo IS de and Valadares-Inglis MC (eds) Recursos Genéticos e Melhoramento - Plantas. Fundação MT, Rondonópolis, pp 201-230.

Ramalho MAP, Santos JB dos and Zimmermann MJ (1993) Genética Quantitativa em Plantas Autógamas - Aplicações ao Melhoramento do Feijoeiro. Editora UFG, Goiânia, 271 pp.

Ranalli P (1996) Phenotypic recurrent selection in common bean (Phaseolus vulgaris L.) basead on performance of $\mathrm{S}_{2}$ progenies. Euphytica 87:127-132.

Sartorato A and Alzate-Marin AL (2004) Analysis of the pathogenic variability of Phaeoisariopsis griseola in Brazil. Ann Rep Bean Improv Coop 47:235-237.

Singh SP and Gutiérrez (1984) Geographical distribution of the $\mathrm{DL}_{1}$ and $\mathrm{DL}_{2}$ genes causing hybrid dwarfism in Phaseolus vulgaris L., their association with seed size, and their significance to breeding. Euphytica 33:337-345.

Singh SP, Terán H, Muñoz CG and Takegami JC (1999) Two cycles of recurrent selection for seed yield in common bean. Crop Sci 39:391-397.

Senior Editor: Ernesto Paterniani 